Large and Rich Phosphorus Resources in the Phosphoria Formation in the Soda Springs Area, Southeastern Idaho

G E O L O G I C A L S U R V E Y B U L L E T I N 14996 



\section{Large and Rich Phosphorus Resources in the Phosphoria Formation in the Soda Springs Area, Southeastern Idaho}

By R. A. GULBRANDSEN and DONATHON J. KRIER

G E O L O G I C A L S U R V E Y B U L L E T I N 1496

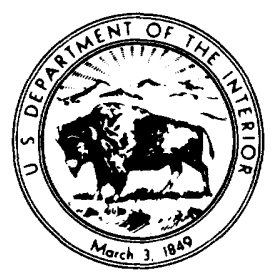




\section{UNITED STATES DEPARTMENT OF THE INTERIOR}

CECIL D. ANDRUS, Secretary

\section{GEOLOGICAL SURVEY}

H. William Menard, Director

Library of Congress catalog-card Number $80-600145$

For sale by the Superintendent of Documents, U. S. Government Printing Office Washington, D. C. 20402 


\section{CONTENTS}

$\begin{array}{rr} & \text { Page } \\ \text { Abstract } & \end{array}$

Introduction _-

Meade Peak Phosphatic Shale Member _..._._. 5

Distribution of phosphorus in the Meade Peak Phosphatic Shale Member _..._. $\quad 5$

Derivation of resource parameters _...... 10

Effects of weathering on rock composition 10

Data from the Conda underground section _._. 12

Resource parameters for the average underground section _...___._._. 14

Resource parameters for the average underground phosphate rock (containing more than 20 weight percent $\left.\mathrm{P}_{22} \mathrm{O}_{5}\right)$

Resource parameters for average surface phosphate rock (containing more than 20 weight percent $\left.\mathrm{P}_{2} \mathrm{O}_{5}\right)$

Phosphorus resource _._._..._._._- 17

Method of calculating the average rock composition of a section in terms of three components

Composition, porosity, and density of average surface phosphate rock (containing more than 20 weight percent $\mathrm{P}_{2} \mathrm{O}_{5}$ )

References cited

\section{ILLUSTRATIONS}

Figure 1. Map showing distribution of the Phosphoria Formation in Soda Springs area, southeastern Idaho

2. Columnar section of the Meade Peak Phosphatic Shale Member at Mabie Canyon

3. Frequency diagrams showing distributions of phosphorus in Conda underground section and in a composite of 17 surface sections _...... 7

4. Graph showing relation of average phosphorus content to proportion of rock that contains more than 20 weight percent $\mathrm{P}_{2} \mathrm{O}_{5}$ in sections of the Meade Peak Phosphatic Shale Member _.___._._._. 9

5. Triangular plot of composition of 17 surface sections, of average surface section, of average underground section, and of Conda underground section

6. Diagrammatic cross section showing resource categories

\section{TABLES}

TABLE 1. Distribution of phosphorus in average surface section and in Conda underground section -._._. 8

2. Average weight percent $\mathrm{P}_{2} \mathrm{O}_{3}$ and proportion of rock that contains more than 20 weight percent $\mathrm{P}_{2} \mathrm{O}_{\mathrm{s}}$ in sections of Meade Peak _..... 9 
TABLE 3. Average rock composition of each section and average for 17 surface

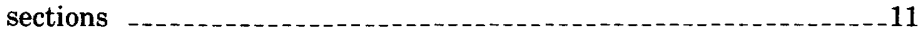

4. Composition, density, and porosity of Conda underground section--.--13

5. Composition, density, and porosity of average underground section--- -15

6. Composition, density, and porosity of average underground phosphate rock that contains more than 20 weight percent $\mathrm{P}_{2} \mathrm{O}_{3}$

7. Resource of phosphorus in the Meade Peak Phosphatic Shale Member in Soda Springs area .................................. 


\title{
LARGE AND RICH PHOSPHORUS RESOURCES IN THE PHOSPHORIA FORMATION IN THE SODA SPRINGS AREA, SOUTHEASTERN IDAHO
}

\author{
By R. A. Gulbrandsen and Donathon J. Krier
}

\section{ABSTRACT}

Concern about the capability of world food production to keep abreast of an everincreasing population has led to concern about the adequacy of phosphorus resources for fertilizers. Studies show that sufficient phosphorus is available for most population projections, but that most resources are of lower grade than those now utilized and that the nature of the deposits is poorly known. U.S. production of phosphorus is also of concern and is projected to fall short of demand in the early years of the next century, on the basis of present-day reserves.

In this preliminary study we assess the nature and magnitude of deeply buried phosphorus resources in the Phosphoria Formation in the Soda Springs area of southeastern Idaho and show that very large and rich phosphate deposits are present. An area of about $760 \mathrm{~km}^{2}$ is estimated to be underlain by about 22 billion tons of phosphate rock that contains 2.7 billion tons of phosphorus-enough to supply U.S. needs far into the future. Beds that contain more than 20 weight percent $\mathrm{P}_{2} \mathrm{O}_{5}$ (avg 27.7 weight percent $\mathrm{P}_{2,} \mathrm{O}_{5}$ ) make up a total thickness that averages $10.6 \mathrm{~m}$. About 44 percent of these resources is shallower than $600 \mathrm{~m}$, and the remainder is no deeper than about $2,000 \mathrm{~m}$. The rock is estimated to yield 78,000 tons of $\mathrm{P}_{2} \mathrm{O}_{5}$ per hectare of bedding plane. How soon these resources can be economically developed has not been well established; some indications are that utilization may be near at hand, but much of the required technology has yet to be developed.

\section{INTRODUCTION}

Concern about the adequacy of world food production for projected increases in global population has led to concern about the supply of phosphorus, an essential element in all living matter, for use in fertilizers. Estimates from a number of studies (McKelvey and others, 1953b; McKelvey, 1967; Sheldon, 1969; Emigh, 1972, 1973, 1975; Cathcart and Gulbrandsen, 1973; Wells, 1975; De Voto and Stevens, 1979) show clearly that known phosphate deposits contain sufficient phosphorus to last far into the future, even without recycling. Only a very small fraction of this phosphorus, however, is classed as reserve, that is, as a resource that can be mined and processed at a profit under present-day (1979) conditions. Recovery of the greater part of this resource will presumably be more costly than at present and will require both changes in technology and the development of new technology. 
Most of these phosphate deposits have received little study, and their nature and magnitude are poorly known. If their resource potential is to be utilized when they are needed, there is a compelling urgency to begin the studies now. For example, Stowasser's (1975) projection of the supply and demand for phosphate rock in the United States, based on an estimate of current reserves, shows demand exceeding supply by about 2005 and the deficit enlarging rapidly after that time.

The most recent study of the resource of phosphorus in the Phosphoria Formation in Idaho, as well as in Montana, Wyoming, and Utah, is the comprehensive assessment by Bauer and Dunning (1979). Although the resource was calculated for all depths, the rock parameters used are in most part applicable only to surface and near-surface rock that is weathered to varying degrees. Because most of the underground rock is unweathered, there is a clear need for information about fresh rock if the accuracy of the resource calculation is to be improved.

In this report we estimate the nature and amount of deeply buried phosphorus resources in phosphate rock of the Meade Peak Phosphatic Shale Member of the Phosphoria Formation in the Soda Springs area (fig. 1). We define a deeply buried resource as one that underlies areas where the surface rock is younger than the Phosphoria Formation (stippled areas, fig. 1). The minimum depth of burial (to top of the Meade Peak) is thus the thickness, ranging from about 61 to $76 \mathrm{~m}$, of other members of the Phosphoria that are stratigraphically above the Meade Peak. All deeply buried, or underground, rock is considered fresh and unweathered, although weathered rock is known to occur in places beyond the boundary thus defined. The remaining phosphorus resource in phosphate rock (calculated below) that lies at or near the surface underlies outcrop areas of the Phosphoria Formation (horizontal line pattern, fig. 1). We classify all of this rock as weathered surface rock, although it also includes fresh rock in some places.

FIgURE 1.-Distribution of the Phosphoria Formation in Soda Springs area, southeastern Idaho. Dots denote locations of stratigraphic sections of the Meade Peak Phosphatic Shale Member of the Phosphoria Formation. Data for localities 1308, 1309, and 1314 are from Davidson, Smart, Peirce, and Weiser (1953); for 1206, 1208, 1211, 1230, and 1233 from McKelvey, Armstrong, Gulbrandsen, and Campbell (1953a); for 1200, 1210 and 1265 from McKelvey, Davidson, O'Malley, and Smith (1953c); for 1258 and 1261 from O'Malley, Davidson, Hoppin, and Sheldon (1953); for 1298, 1303, and 1310 from Sheldon, Warner, Thompson, and Peirce (1953); for 1372 from Smart, Waring, Cheney, and Sheldon (1954); and for 1306A from Montgomery and Cheney (1967). Map modified from Mabey and Oriel (1970). 
R. $42 \mathrm{E}$.

R. $43 \mathrm{E}$.

R. $44 \mathrm{E}$.

R. $45 \mathrm{E}$.

R. $46 \mathrm{E}$.

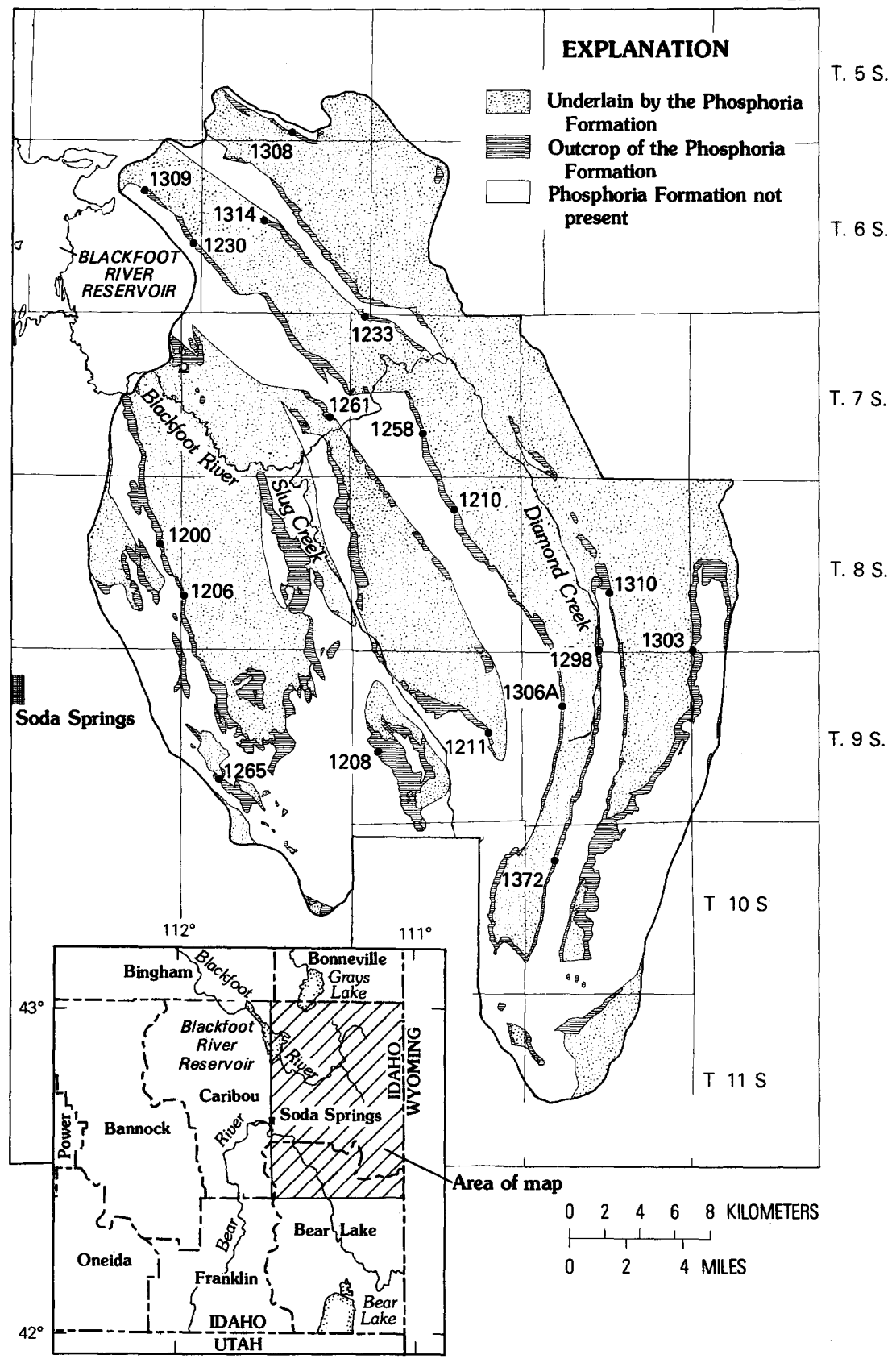


Finally, we calculate the total phosphorus in the entire Meade Peak.

The parameters needed for our resource calculations are grade, thickness, density, and area of rock. The area measurement is straightforward; the other parameters, where not measured, are indirectly derived. The key factors for determining the total amount of deeply buried resource are: (1) the frequency mode of phosphorus in the class of rock that contains more than 20 weight percent $\mathrm{P}_{2} \mathrm{O}_{5}$, (2) the relation of the amount of rock that contains more than 20 percent $\mathrm{P}_{2} \mathrm{O}_{5}$ to the average $\mathrm{P}_{2} \mathrm{O}_{5}$ content (in weight percent) of a section, and (3) the relation between rock density, porosity, and mineral composition. Data from one underground section in the area, the Conda mine, are essential to all estimates of these parameters for average underground phosphate rock and for total rock of the Meade Peak. The Conda section is about $180 \mathrm{~m}$ downdip from the surface. With the exception of some parts of the section that have been exposed to ground water along joints and highly fractured zones, as well as a few soft beds rich in organic matter, the rock is brownish gray to black, hard, and well cemented.

The extensive available information about the phosphate deposits and geology of the Soda Springs area is one of our principal reasons for selecting this area for study. Broad coverage was provided by Mansfield (1927) and Hale (1967a). The entire area (fig. 1) was mapped geologically by Mansfield at scales of 1:62,500 and 1:125,000; larger scale geologic maps for much of the area were prepared by Cressman and Gulbrandsen (1955), Gulbrandsen, McLaughlin, Honkala, and Clabaugh (1956), Cressman (1964), Montgomery and Cheney (1967), Armstrong (1969), and Rioux, Hite, Dyni, and Gere (1975). Mabey and Oriel (1970) prepared a geologic map at a scale of 1:125,000 that includes all of the Soda Springs area.

The regional structure interpreted by Rubey and Hubbert (1959), Armstrong and Cressman (1963), and Cressman (1964) is followed in this report and affects our interpretation of the subsurface geology in some places. If thrust faults underlie the area, additional phosphate deposits of the Meade Peak may also be present in the underlying plates. We have not investigated this possibility further, however, because of insufficient data for evaluation. Stratigraphic sections of the Meade Peak (see fig. 1 for locations) provided most of the basic data on the rocks used in the resource assessment (see fig. 1 caption for references).

Acknowledgment. - Many of the data for this study were collected directly by V. E. McKelvey or under his supervision. His interest in phosphorus resources, especially those in the Phosphoria Formation, extends over a period of more than 30 years, and he has contributed greatly to our present-day knowledge of these resources and their 
origin. Stimulation from his work and through personal association with him has aided the senior author in the preparation of this report and is greatly appreciated. We also appreciate assistance by J. G. Moore in clarifying aspects of rock density. P. Jones and D. Krier assisted with organic-matter determinations on samples of the Conda underground section.

\section{MEADE PEAK PHOSPHATIC SHALE MEMBER}

The Meade Peak Phosphatic Shale Member of the Phosphoria Formation contains the principal phosphate deposits of the Soda Springs area in southeastern Idaho. These deposits are the richest of all those in the Phosphoria Formation of the Western Field and yielded about 4.1 million tons of phosphate rock from four mines in 1978. The reserve in the area, totaling about 1 billion tons of phosphate rock (modified from Garrand's (1974) estimate) along the outcrops or margins of segments of marine blanket deposits, makes up only a small fraction of the deeply buried resources that extend beneath younger units over large areas.

McKelvey and others (1959) described the stratigraphy and nomenclature of the Phosphoria Formation. In the Soda Springs area the Phosphoria Formation consists, in ascending order, of the Meade Peak Phosphatic Shale Member, the Rex Chert Member, a cherty shale member, and, in the eastern part of the area, the Retort Phosphatic Shale Member. The Retort, which interfingers with the cherty shale member, is not economically significant in the Soda Springs area.

A columnar section (fig. 2) of the Meade Peak at Mabie Canyon (loc. 1210 , fig. 1) shows the main ore zones currently being mined and a generalized distribution of the three main rock types: phosphate rock, mudstone (quartz-silicate rock), and carbonate rock. Thickness of the Meade Peak in the area ranges from 33 to about $62 \mathrm{~m}$ and is estimated to average $54 \mathrm{~m}$. The average phosphorus content of 17 surface sections ranges from about 10 to nearly 17 weight percent $\mathrm{P}_{2} \mathrm{O}_{5}$, and the average for the area is estimated at 13.4 weight percent $\mathrm{P}_{2} \mathrm{O}_{5}$. One underground section, the Conda mine (loc. 1200, fig. 1), is $60.7 \mathrm{~m}$ thick and contains an average of 9.4 weight percent $\mathrm{P}_{2} \mathrm{O}_{5}$.

\section{DISTRIBUTION OF PHOSPHORUS IN THE MEADE PEAK PHOSPHATIC SHALE MEMBER}

The distribution of phosphorus in a composite of 17 surface sections (fig. 3) shows a marked secondary frequency mode, possibly even two modes, in the concentration classes between 20 and 39 weight percent $\mathrm{P}_{2} \mathrm{O}_{5}$. This mode, which includes most of the rock being mined, shows the unusual phosphorus richness of the Meade Peak. Most significantly, this same mode also appears in the frequency distribu- 


\section{EXPLANATION}

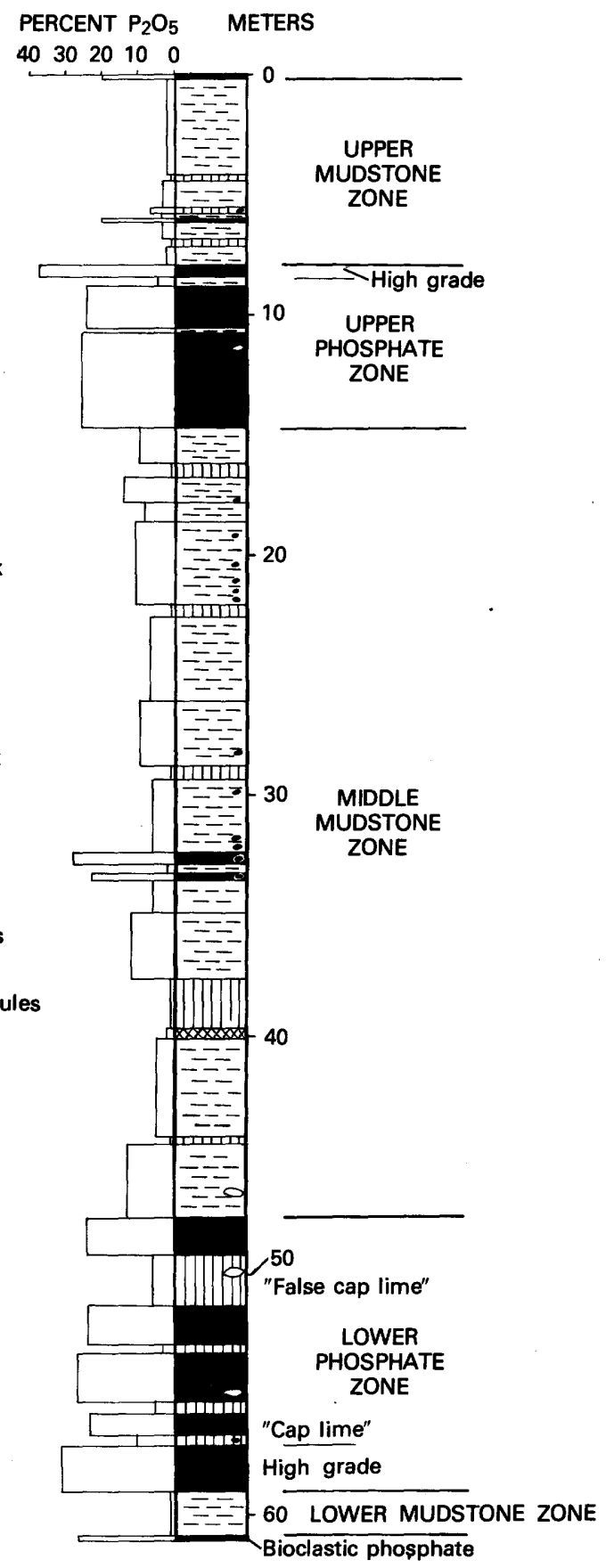

Figure 2.-Columnar section of the Meade Peak Phosphatic Shale Member at Mabie Canyon (loc. 1210, fig. 1). Data from McKelvey, Davidson, O'Malley, and Smith (1953c). 


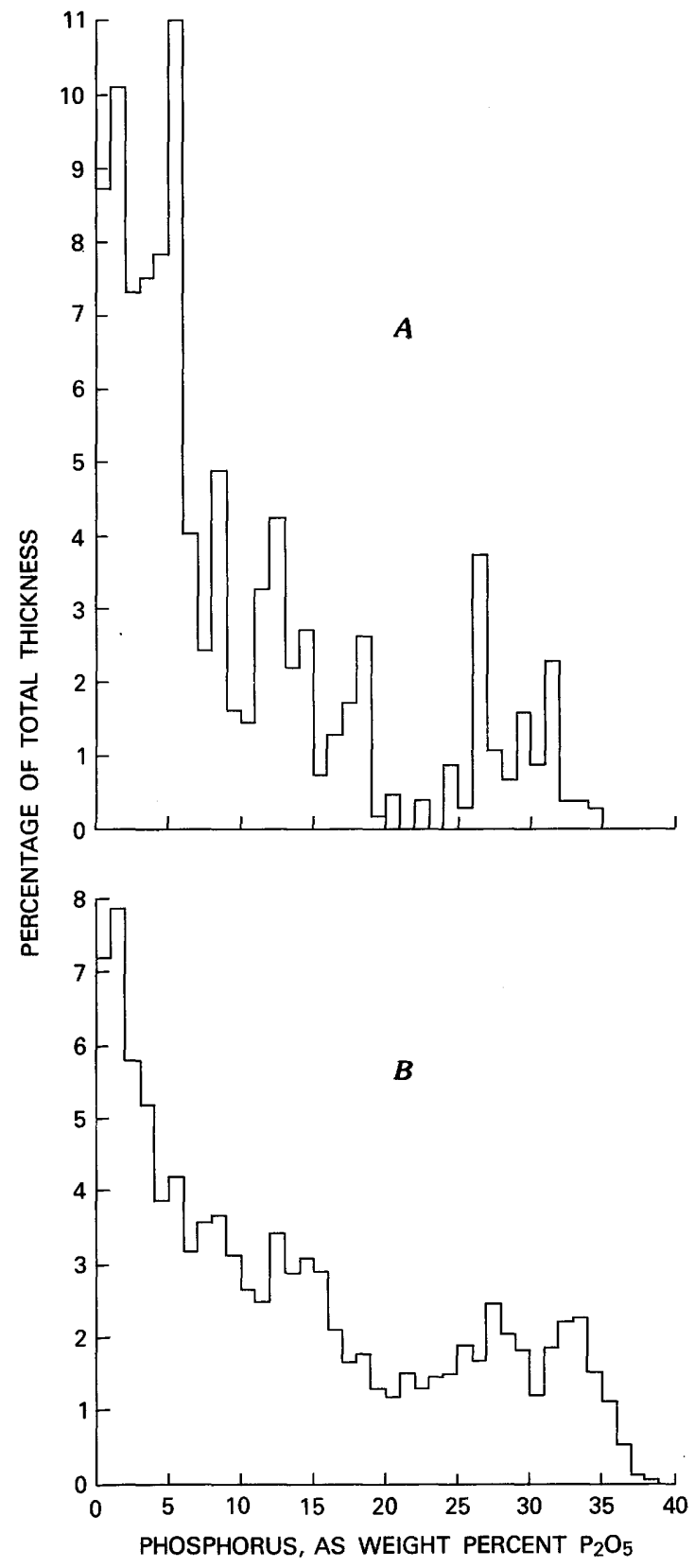

FigURE 3.-Distribution of phosphorus (in 1weight-percent- $\mathrm{P}_{2} \mathrm{O}_{\overline{5}}$ classes) in the Conda underground section $(A)$ and in a composite of 17 surface sections $(B)$. 
tion for the Conda underground section (fig. 3). The mode is therefore not a product of weathering but a primary feature in the formation of the phosphate deposits, important to the future development of the deeply buried resource. For this reason we have selected the class of phosphate rock that contains more than 20 weight percent $\mathrm{P}_{2} \mathrm{O}_{5}$ for the resource calculation. Furthermore, the frequency mode in the upper range of $\mathrm{P}_{2} \mathrm{O}_{5}$ values shows that the abundance of rock throughout the entire distribution does not increase regularly with decreasing grade-an important factor to consider in the mining of lower grade rock.

The principal difference between these two distributions is the much larger proportion in the Conda underground section of rock that contains less than 7 weight percent $\mathrm{P}_{2} \mathrm{O}_{5}$. A comparison of the lowgrade $\left(0-10\right.$ weight percent $\left.\mathrm{P}_{2} \mathrm{O}_{5}\right)$ rock classes for the two distributions (table 1) shows that the Conda section has 18 percent more rock of this grade than does the average surface section. This feature appears to account for the main part of the difference between the average $\mathrm{P}_{2} \mathrm{O}_{5}$ content of the whole Conda section (9.4 weight percent $\mathrm{P}_{2} \mathrm{O}_{5}$ ) and the average for the surface sections (13.4 weight percent $\mathrm{P}_{2} \mathrm{O}_{5}$ ). The Conda section is below average in $\mathrm{P}_{2} \mathrm{O}_{5}$ content even when weathering effects are taken into account, as shown below.

TABLE 1.-Distribution of phosphorus in average surface section and in Conda underground section (in 5-weight-percent $-\mathrm{P}_{2} \mathrm{O}_{5}$ classes)

\begin{tabular}{ccc}
\hline \multirow{2}{*}{$\begin{array}{c}\text { Class } \\
\text { (weight percent } \mathrm{P}_{2} \mathrm{O}_{5} \text { ) }\end{array}$} & \multicolumn{2}{c}{ Percentage of total thickness } \\
\cline { 2 - 3 } & $\begin{array}{c}\text { Average } \\
\text { surface section }\end{array}$ & $\begin{array}{c}\text { Conda } \\
\text { underground section }\end{array}$ \\
\hline $0-5$ & 29.92 & 41.59 \\
$5-10$ & 17.82 & 24.11 \\
$10-15$ & 14.53 & 14.01 \\
$15-20$ & 9.83 & 6.68 \\
$20-25$ & 6.98 & 1.81 \\
$25-30$ & 9.94 & 7.48 \\
$30-35$ & 9.10 & 4.32 \\
35 & 1.88 & 0 \\
\hline
\end{tabular}

One important feature of the distribution of phosphorus in the different sections is the relation of average phosphorus content (in weight percent $\mathrm{P}_{2} \mathrm{O}_{5}$ ) to the proportion (in percent) of rock in the section that contains more than 20 weight percent $\mathrm{P}_{2} \mathrm{O}_{5}$. These data (table 2) show that the correlation between these two parameters is very good: the correlation coefficient is 0.97 . The line fitted to the data points (fig. 4) is the calculated line of linear regression. The Conda underground section has the lowest average weight percent $\mathrm{P}_{2} \mathrm{O}_{5}$ and the lowest proportion of rock that contains more than 20 weight percent $\mathrm{P}_{2} \mathrm{O}_{5}$; the North Rasmussen Valley section (loc. 1233, fig. 1) has the highest of both. The correlation of averages with proportions is an 
TABLE 2.-Average weight percent $\mathrm{P}_{3} \mathrm{O}_{3}$ and proportion of rock that contains more than 20 -weight-percent $\mathrm{P}_{3} \mathrm{O}_{5}$ in sections of the Meade Peak

\begin{tabular}{|c|c|c|c|}
\hline Locality & Name & $\begin{array}{l}\text { Average weight } \\
\text { percent } \mathrm{P}_{2} \mathrm{O}_{5}\end{array}$ & $\begin{array}{c}\text { Proportion of rock } \\
\text { in section that } \\
\text { contains more than } \\
20 \text { weight percent } \\
\text { (percent) }\end{array}$ \\
\hline 1200 & Conda mine & 9.4 & 13.6 \\
\hline 1206 & Trail Canyon - & 10.5 & 17.6 \\
\hline 1208 & West Dairy & 12.8 & 26.7 \\
\hline 1210 & Mabie Canyon & 11.2 & 22.9 \\
\hline 1211 & South Dry Valley & 13.3 & 28.2 \\
\hline 1230 & North Wooley Range & 15.3 & 32.9 \\
\hline 1233 & North Rasmussen Valley & 16.7 & 37.4 \\
\hline 1258 & Kendall Canyon & 13.8 & 29.0 \\
\hline 1261 & Blackfoot Narrows & 13.0 & 25.8 \\
\hline 1265 & Swan Lake Gulch & 10.1 & 17.4 \\
\hline 1298 & Lone Pine Springs & 14.2 & 31.7 \\
\hline 1303 & Pole Canyon & 15.2 & 29.5 \\
\hline $1306 \mathrm{~A}$ & 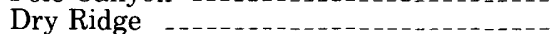 & 13.1 & 27.2 \\
\hline 1308 & Gravel Creek Divide & 14.8 & 31.2 \\
\hline 1309 & - & 13.0 & 28.7 \\
\hline 1310 & Timber Creek & 13.6 & 27.7 \\
\hline 1314 & Enoch Valley & 15.3 & 33.6 \\
\hline 1372 & Snowdrift Mountain & 14.2 & 32.6 \\
\hline
\end{tabular}

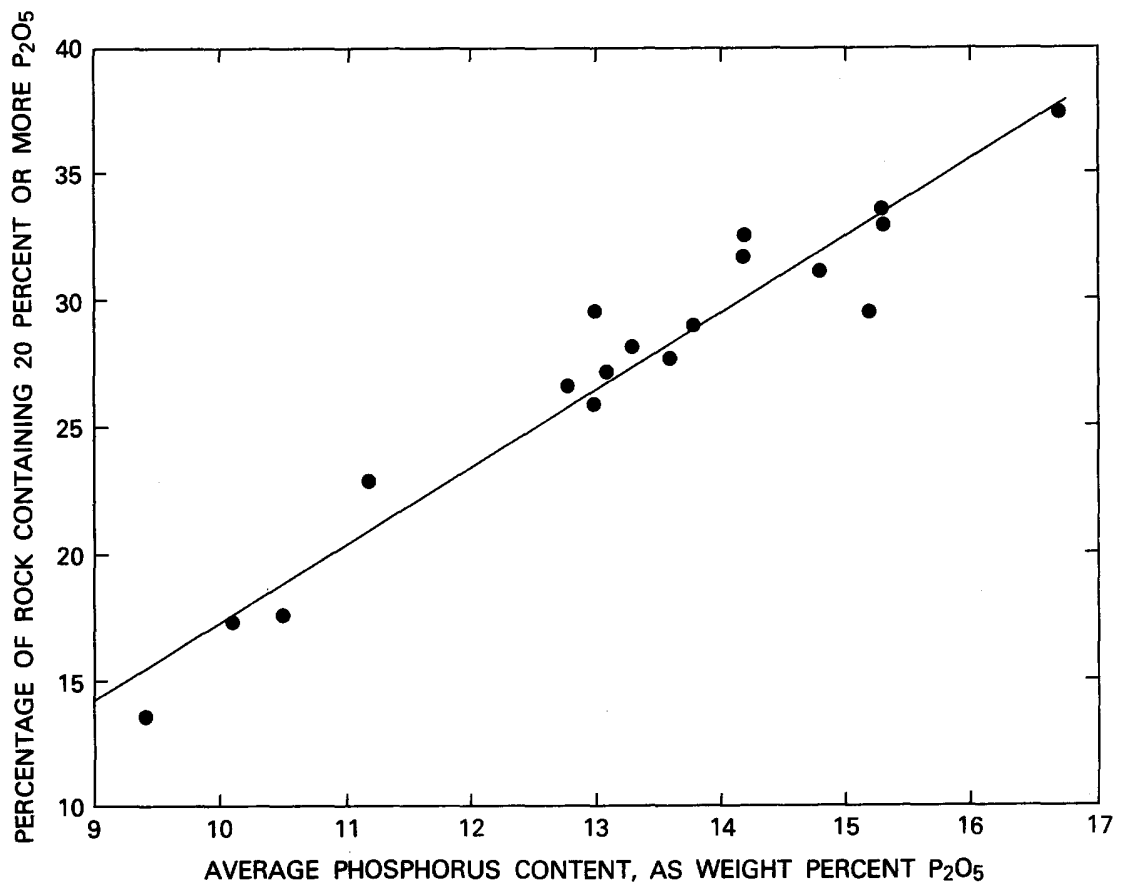

FigURE 4.-Relation of average phosphorus content (in weight percent $\mathrm{P}_{2} \mathrm{O}_{5}$ ) to proportion of rock that contains more than 20 weight percent $\mathrm{P}_{2} \mathrm{O}_{3}$ in sections of the Meade Peak Phosphatic Shale Member. Line fitted to data points is calculated line of linear regression. 
inherent relation, but the degree of correlation makes this relation particularly useful and is utilized below to estimate the proportion of rock in the average underground section that contains more than 20 weight percent $\mathrm{P}_{2} \mathrm{O}_{5}$.

\section{DERIVATION OF RESOURCE PARAMETERS}

\section{EFFECTS OF WEATHERING ON ROCK COMPOSITION}

The principal effect of weathering on fresh rock of the Meade Peak Phosphatic Shale Member in the temperate semiarid climate of the Soda Springs area is the loss of calcite, dolomite, and organic matter by solution and oxidation (Carswell and Gulbrandsen, 1954; Hale 1967b; Altschuler, 1973; Emigh, 1973). Leaching of these primary rock components from the rock creates a porosity equivalent to the volume of components lost. Essential retention of the primary rock volume is indicated by the coherence of the rock and the preservation of bedding features. Where the loss of components is large, however, such as from limestone, the primary rock volume may be reduced to one supported by the relatively insoluble residual components. Pyrite is also destroyed by weathering, but the iron is converted to ferric oxide, which remains in the rock, and so any change in rock volume is small. The sulfur is oxidized, rarely to native sulfur and more commonly to soluble sulfate that is either carried away or deposited as gypsum along fracture surfaces. Gypsum of this origin is common in much of the rock of the Conda underground mine.

To illustrate the effects of weathering on rock composition, we here express the average composition of each section in the area in terms of three components:

(1) apatite-used in place of carbonate fluorapatite, the full mineral name;

(2) OM-carb-a combination of organic matter (OM) and the carbonate minerals (carb) calcite and dolomite;

(3). Q-S-the remainder of the rock, chiefly quartz, potassium feldspar, buddingtonite, albite, muscovite-illite, kaolinite, montmorillonite, pyrite, and possibly goethite.

The apatite component is the product of the average weight percent $\mathrm{P}_{2} \mathrm{O}_{5}$ and the factor 2.6. The OM-carb component is estimated by a calculation involving the proportions of $\mathrm{OM}$ and the $\mathrm{CO}_{2}$ attributed to dolomite and calcite in the chemical composition of average phosphorite of the Meade Peak (Gulbrandsen, 1966), average quartz-silicate rock, and average carbonate rock of the Meade Peak (Gulbrandsen, 1975), and involving the percentages of these rock types in surface sections of the area (see p. 21). The OM-carb component for the Conda section is calculated independently, from organic-matter determina- 
tions on samples of the section and from loss-on-ignition (LOI) values reported by McKelvey, Davidson, O'Malley, and Smith (1953c). The last rock component, Q-S, constitutes the remainder of the rock. The values of the three compositional components for all sections and the average for 17 surface sections are given in a comprehensive list (table 3) and plotted together on a triangular diagram (fig. 5).

TABLE 3.-Average rock composition of each section and average for 17 surface sections expressed in three components (in weight percent)

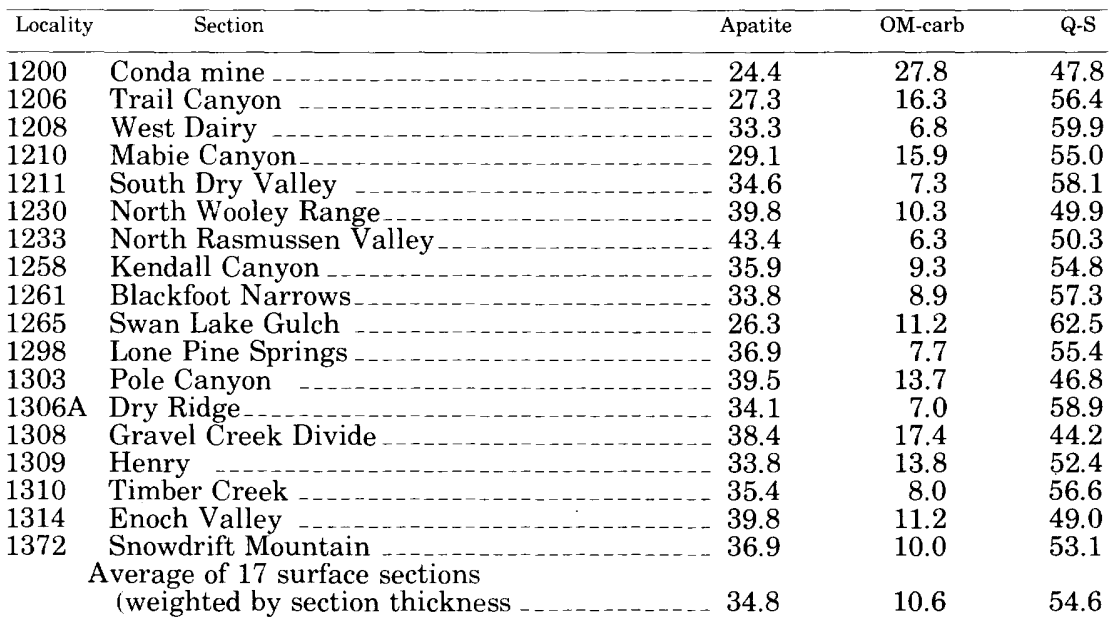

Assuming that only organic matter and carbonate minerals are removed from the rock during weathering, the path of weathering for each section (fig. 5) is along a line that extends from the OM-carb apex, through the section point, to the boundary of the diagram, where the component is zero. Such a line is shown for the Conda underground section (1200). This potential weathering path passes close to the point for Trail Canyon (1206), a nearby surface section. The weathering path, which illustrates the removal of OM-carb from the rock, is also a line of constant ratio of the other two components; the percentage of each component increases as weathering proceeds, but their ratio remains the same. The Conda section, for example, has 24.4 percent apatite, 47.8 percent Q-S, and a ratio of apatite to Q-S of 0.51 . If weathering had removed all the OM-carb, the compositional point for this section would be at the intersection of the weathering path with the boundary of the diagram, and the section would have a composition of 33.7 percent apatite and 66.3 percent Q-S in the same ratio $(0.51)$ as above.

The compositions of the surface sections show a range in degree of weathering; none shows OM-carb completely removed, but all show a marked degree of weathering relative to the Conda underground sec- 


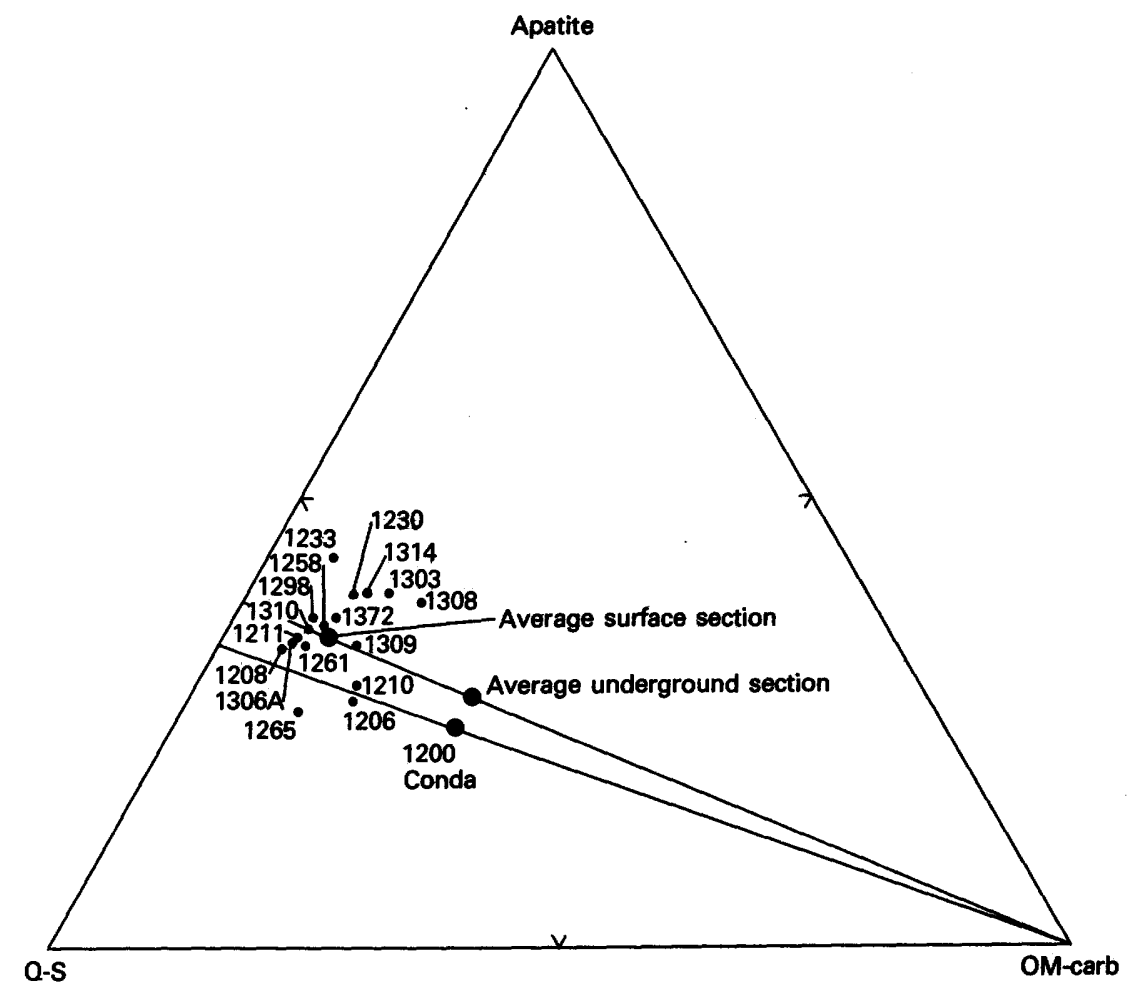

FIGURE 5.-Triangular plot of composition (in weight percent) of 17 surface sections, of average surface section, of average underground section, and of Conda underground section. OM-carb is combined organic matter and carbonate minerals; Q-S, combined quartz, silicate minerals, and miscellaneous minerals. Numbers refer to section localities (fig. 1, tables 2, 3).

tion. The composition of the average surface section is also plotted (fig. 5), and a weathering-path line is drawn through this point. Ideally, we would like to reverse the weathering of the average surface section, replace the lost constituents, and thereby obtain a complete composition for the average underground section. All that we know directly about the average underground section is that its ratio of apatite to Q-S is the same as in the average surface section and that its compositional point (fig. 5) lies somewhere on the line between the compositional point for the average surface section and the OM-carb apex. We may estimate the variables needed-OM-carb and porosity - from the data for the Conda section; this estimate allows us to calculate the actual proportions of apatite and Q-S as well as the rock density.

\section{DATA FROM THE CONDA UNDERGROUND SECTION}

From the known composition and the measured density, we may 
calculate the porosity of the Conda underground section as follows. The average bulk density of the section is $2.49 \mathrm{~g} / \mathrm{cm}^{3}$ on the basis of 80 determinations, a value that represents the total weight in grams of the mineral components in $1 \mathrm{~cm}^{3}$ of rock (table 4). The grain density is $2.603 \mathrm{~g} / \mathrm{cm}^{3}$, the total weight of mineral components divided by the sum of mineral volumes. The equations for these relations are:

TABLE 4-Composition, density, and porosity of Conda underground section.

\begin{tabular}{|c|c|c|c|c|c|}
\hline Component & $\begin{array}{l}\text { Weight } \\
\text { percent }\end{array}$ & $\underset{\left(\mathrm{g} / \mathrm{cm}^{1}\right)}{D^{1}}$ & $r V^{3}$ & $\begin{array}{c}V^{6} \\
\left(\mathrm{~cm}^{3}\right)\end{array}$ & $\begin{array}{l}W^{7} \\
(\mathrm{~g})\end{array}$ \\
\hline $\begin{array}{l}\text { Apatite } \\
\text { Carb } \\
\text { OM } \\
\text { Q-S }\end{array}$ & $\begin{array}{r}24.4 \\
19.8 \\
8.0 \\
47.8\end{array}$ & $\begin{array}{r}{ }^{*} 3.2 \\
92.8 \\
10 \\
1.5 \\
{ }^{11} 2.6\end{array}$ & $\begin{array}{r}0.0763 \\
.0707 \\
.0533 \\
.1838 \\
\end{array}$ & $\begin{array}{r}0.1900 \\
.1760 \\
.1327 \\
.4577 \\
\end{array}$ & $\begin{array}{r}0.6080 \\
.4928 \\
.1991 \\
1.1900 \\
\end{array}$ \\
\hline Void & & Subtotal & $\begin{array}{r}12.3841 \\
.0175 \\
\end{array}$ & $\begin{array}{l}.9564 \\
.0436 \\
\end{array}$ & \\
\hline . & & Total & ${ }^{13.4016}$ & 1.0000 & 2.4899 \\
\hline
\end{tabular}

Known variables: weight percent, $D,{ }^{1}$ and $D_{t}{ }^{2}$.

Sequence of calculations:

(1) to obtain porosity: $r V_{\text {commronents, }} r V_{\text {suhtutal }}, D_{y},{ }^{3}$ and $P ;^{+}$

(2) to complete data of the table: $r V_{\text {tortal }}, r V_{\text {virit }}, V$, and $W$.

' $D=$ density of mineral components $\left(\mathrm{g} / \mathrm{cm}^{3}\right)$.

${ }^{2} D_{b}=$ bulk density of rock $\left(\mathrm{g} / \mathrm{cm}^{3}\right)=r V_{\text {total }}=W_{\text {total }}$.

$$
1
$$

${ }^{3} D_{n}=$ grain density of rock $\left(\mathrm{g} / \mathrm{cm}^{\text {in }}\right)=r V_{\text {suttental }}=W_{\text {totat }} / V_{\text {subtutal }}$

${ }^{4} P_{p}=$ porosity of rock $=100\left(1-D_{b} / D_{v}\right)=100\left(V_{\text {visid }}\right)$.

${ }^{5} \mathrm{rV}=$ relative volume $=$ weight percent $/ 100 \mathrm{D}$

" $V=$ volume $\left(\mathrm{cm}^{3}\right)=r V$ calculated to total of $1 \mathrm{~cm}^{3}$

${ }^{7} \mathrm{~W}=$ weight $(\mathrm{g})=D V$.

${ }^{\text {N }}$ Calculated for carbonate fluroapatite from chemical analyses and unit-cell dimensions

${ }^{y}$ Dolomite-calcite density is intermediate in value between densities of dolomite and calcite and favors dolomite.

"Grain density of organic-matter separate

"Grain density of quartz and silicate mineral separate

${ }^{12} r V_{\text {subtutal }}=$ sum of $r V$ cumpenents $=1 / D_{s}$.

${ }^{13} r V_{\text {tutat }}=r V_{\text {subtutal }}+r V_{\text {vited }}=1 / D_{b}$.

$D_{b}=\frac{W_{\text {apatite }}+W_{\text {carb }}+W_{\mathrm{OM}}+W_{\mathrm{Q}-\mathrm{S}}}{V_{\text {apatite }}+V_{\text {carb }}+V_{\mathrm{OM}}+V_{\mathrm{Q}-\mathrm{S}}+V_{\text {void }}}=\frac{W_{\text {total }}}{V_{\text {total }}}$

and $\quad D_{y}=\frac{W_{\text {total }}}{V_{\text {total }}-V_{\text {void }}}$

where $D_{b}=$ bulk density $\left(\mathrm{g} / \mathrm{cm}^{3}\right)$,

$D_{g}=$ grain density $\left(\mathrm{g} / \mathrm{cm}^{3}\right)$,

$W=$ weight $(\mathrm{g})$, 
and $V=$ volume $\left(\mathrm{cm}^{3}\right)$.

The density is related to the porosity $P$ (in volume percent void) of rock by

$$
P=100\left(1-\frac{D_{b}}{D_{g}}\right)
$$

The porosity of the Conda underground section, therefore, is 4.4 percent, about the same as the lowest porosity that Athy (1930) found for shale at a burial depth of about $1,800 \mathrm{~m}$. The Meade Peak in this area was buried much deeper, at least $6,000 \mathrm{~m}$, and subjected later in its history to additional forces exerted during orogeny. This porosity is probably near the minimum attainable by pressure alone without recrystallization.

The volumes of OM-carb (table 4) show that the complete removal of those components would create a rock porosity of 35 percent, including the primary porosity. This porosity, particularly as an average, appears likely to be near the maximum attainable without the collapse of many beds. Hedberg (1936, p. 277) found in compaction studies of clay that significant grain contacts are not attained until the porosity is lowered to about 30 to 35 percent. The density for Conda rock of 35-percent porosity would be $1.80 \mathrm{~g} / \mathrm{cm}^{3}$, from the sum of the weights of the remaining components. This value is low for rock density, particularly because many rocks of the section would therefore have to have densities significantly below this figure. In the constant-volume system that we are considering, therefore, the high porosity and low density calculated for a section from which all the OM-carb has been removed by weathering indicate that the proportion of combined organic matter and dolomite-calcite in the Conda underground section (27.8 percent) must be near the maximum for the Meade Peak in the area.

\section{RESOURCE PARAMETERS FOR THE AVERAGE UNDERGROUND SECTION}

On the basis of the above discussion, the proportion of OM-carb in the average underground section is taken to be 27.8 percent ( 8.0 percent $O M$ and 19.8 percent carb), the same proportion as in the Conda underground section and about the maximum that could be present. Although the proportion of OM-carb could be less than this value, the porous nature of much of the surface rock indicates that it would not differ greatly.

The proportions of apatite and Q-S in the average underground section can now be calculated. Apatite and Q-S are present in a ratio of 0.637 , the same ratio as for the average surface section, and make up 72.2 percent (100 minus 27.8 percent for OM-carb) of the total 
mineral content. Thus the rock contains 28.1 percent apatite and 44.1 percent Q-S (see data in table 5). This proportion of apatite is equivalent to 10.8 weight percent $\mathrm{P}_{2} \mathrm{O}_{5}$, the grade of the average underground section. The porosity of the average underground rock (4.4 percent) is also the same as that for the Conda underground section and is considered unlikely to be in great error.

From these data, we calculate the density of the average underground section to be $2.51 \mathrm{~g} / \mathrm{cm}^{3}$ (table 5 ). The greatest density of the underground counterparts of the sections (shown in fig. 5) determined in this way is $2.53 \mathrm{~g} / \mathrm{cm}^{3}$ for the Gravel Creek Divide (1308) and North Rasmussen Valley (1233) sections, which have the highest ratios of apatite to Q-S. The smallest calculated density is $2.48 \mathrm{~g} / \mathrm{cm}^{3}$, a projection for the Swan Lake Gulch (1265) section, which has the lowest ratio of apatite to Q-S. The only other known estimate for underground rock of the Meade Peak in southeastern Idaho is one we made on a section in the underground Hot Springs mine of the Stauffer Chemical Co., south of this area, near the northeast end of Bear Lake. The average density of 21 samples taken systematically across this section was $2.57 \mathrm{~g} / \mathrm{cm}^{3}$, a value somewhat higher than the 2.51 $\mathrm{g} / \mathrm{cm}^{3}$ estimated for the average underground section in this area but close enough to make us confident in our calculations and to be useful, without great error, in estimating the total amount of phosphorus in the Meade Peak in the Soda Springs area - that is, the total resource present.

The average thickness of the average underground section, the last parameter needed, is taken to be equal to that of the average surface

TABLE 5.-Composition, density, and porosity of average underground section

[See table 4 for explanation of terms]

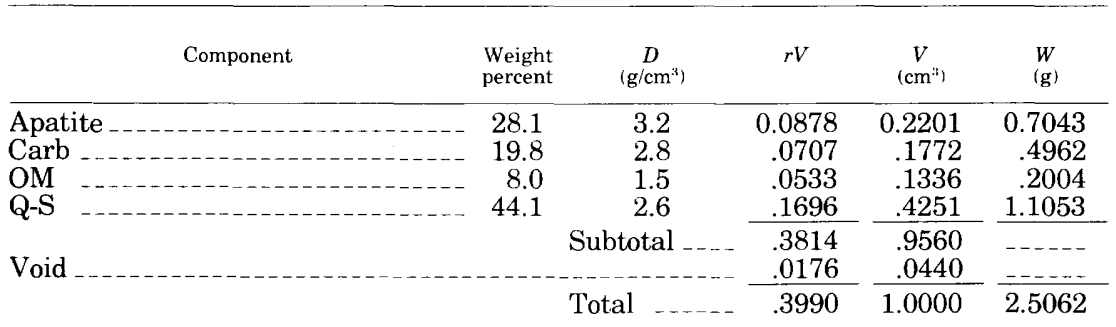

Known variables: weight percent, $D$; and $P=4.4$ percent $=100 \mathrm{~V}_{\text {vwill }}$.

Sequence of calculations:

(1) To obtain density: $r V_{\text {rumpunent, }} r V_{\text {suhtutal }}$,

$V_{\text {subtutal }}=V_{\text {total }}-V_{\text {viul }}=1-0.0440=0.9560$,

$r V_{\text {tutal }}=r V_{\text {subtital }} V_{\text {suttutat }}=0.3814 / 0.9560=0.3990$,

and $D_{t}=1 / r V_{\text {tutal }}=1 / 0.3990=2.51$.

(2) To complete data of table: $r V_{\text {soirl }}, V$, and $W$. 
section $(54 \mathrm{~m})$ but is probably somewhat greater owing to the partial collapse of some surface beds due to weathering.

\section{RESOURCE PARAMETERS FOR AVERAGE \\ UNDERGROUND PHOSPHATE ROCK \\ (CONTAINING MORE THAN 20 WEIGHT PERCENT $P_{2} O_{;}$)}

The relations described above allow us to make reasonable estimates of the parameters for underground phosphate rock (containing more than 20 weight percent $\mathrm{P}_{2} \mathrm{O}_{5}$ ) that are needed in resource calculations: grade, thickness, and density.

An examination of the distribution of rock that contains more than 20 weight percent $\mathrm{P}_{2} \mathrm{O}_{2}$ (fig. 3) shows that the average composition of both underground and surface rocks is less than 30 and greater than 25 weight percent $\mathrm{P}_{2} \mathrm{O}_{5}$. (The actual averages are 27.7 weight percent $\mathrm{P}_{2} \mathrm{O}_{5}$ for underground rock of the Conda section and 28.0 weight percent $\mathrm{P}_{2} \mathrm{O}_{5}$ for the surface rock.) Although the range in $\mathrm{P}_{2} \mathrm{O}_{5}$ content above 20 weight percent is expectably lower in the Conda underground rock, the modal tendencies of both underground and surface rocks suggest that the average $\mathrm{P}_{2} \mathrm{O}_{5}$ content of all underground phosphate rock is not likely to be much lower than the average for the surface rock and is probably appreciably greater than 25 weight percent $\mathrm{P}_{2} \mathrm{O}_{5}$. The average for the Conda rock is therefore taken as an approximation to the true underground average $\mathrm{P}_{2} \mathrm{O}_{5}$ content and appears likely to fall within 1 weight percent $\mathrm{P}_{2} \mathrm{O}_{5}$ of this average.

The thickness of underground phosphate rock is obtained from the relation of thickness to the average $\mathrm{P}_{2} \mathrm{O}_{5}$ content for the entire Meade Peak Phosphatic Shale Member (fig. 4). The average of 10.8 weight percent $\mathrm{P}_{2} \mathrm{O}_{5}$, therefore, gives a thickness of $10.6 \mathrm{~m}$ (19.7 percent of section times total thickness of $54 \mathrm{~m}$ ) for the underground phosphate rock. The thickness of the Conda phosphate rock, by way of comparison, is significantly less: $8.3 \mathrm{~m}$.

The third parameter, density, is taken to be $2.64 \mathrm{~g} / \mathrm{cm}^{3}$, the average measured density of the Conda phosphate rock. Like the grade of rock in the average underground section, this density approximation is expected to fall close to the true average density of average underground phosphate rock.

We further use the composition and density of the underground phosphate rock and all data on the Conda phosphate rock to calculate the rock's porosity (table 6 ).

\section{RESOURCE PARAMETERS FOR AVERAGE SURFACE PHOSPHATE ROCK (CONTAINING MORE THAN 20 WEIGHT PERCENT P.,}

Although the resource of phosphorus in surface phosphate rock is not the principal focus of this paper, we calculate it here to estimate 
TABLE 6.-Composition, density, and porosity of average underground phosphate rock that contains more than 20 weight percent $P_{2} \mathrm{O}_{5}$

[See table 4 for explanation of terms. All data on Conda rock appear closely to approximate those for average underground phosphate rock]

\begin{tabular}{|c|c|c|c|c|c|c|}
\hline & Component & $\begin{array}{l}\text { Weight } \\
\text { percent }\end{array}$ & $\underset{\left(\mathrm{g} / \mathrm{cm}^{3}\right)}{D}$ & $r V$ & $\underset{\left(\mathrm{cm}^{3}\right)}{V}$ & $\begin{array}{l}W \\
(\mathrm{~g})\end{array}$ \\
\hline $\begin{array}{l}\text { Apat } \\
\text { Carb } \\
\text { OM } \\
\text { Q-S }\end{array}$ & $\begin{array}{l}-1 \\
-1\end{array}$ & $\begin{array}{r}72.0 \\
6.8 \\
6.8 \\
14.4\end{array}$ & $\begin{array}{l}3.2 \\
2.8 \\
1.5 \\
2.6\end{array}$ & $\begin{array}{r}0.2250 \\
.0243 \\
.0453 \\
.0554 \\
\end{array}$ & $\begin{array}{r}0.5940 \\
.0642 \\
.1196 \\
.1462 \\
\end{array}$ & $\begin{array}{r}1.9008 \\
.1798 \\
.1794 \\
.3801 \\
\end{array}$ \\
\hline \multirow[t]{2}{*}{ Void } & & & Subtotal _... & $\begin{array}{r}.3500 \\
.0288 \\
\end{array}$ & $\begin{array}{l}.9240 \\
.0760 \\
\end{array}$ & - \\
\hline & & & Total _ _._. & .4788 & 1.0000 & 2.6401 \\
\hline
\end{tabular}

Known variables: weight percent, $D$, and $D_{t}=2.64$.

Sequence of calculations:

(1) To obtain porosity $(P): r V_{\text {cumpenents, }} r V_{\text {subtutal }}$,

$D_{i j}=1 / r V_{\text {sultotal }}=1 / 0.35=2.857$,

$D_{b} \quad 2.64$

and $P=100\left(1-D_{q}\right)=100(1-2.857)=7.6$ percent.

(2) To complete data of table: $r V_{\text {thtal }}=1 / D_{b}, r V_{\text {vwil }}, V$, and $W$.

the total resource of this class in the Soda Springs area. The rock parameters we need are the same as those for the underground rock: grade, thickness, and density. The grade and thickness have been measured for 17 sections and average 28 weight percent $\mathrm{P}_{2} \mathrm{O}_{5}$ and 15 $\mathrm{m}$, respectively. Although samples for density determinations are not presently available, we have estimated the average density. (For method of calculation, see p. 22.) The calculated density is $2.39 \mathrm{~g} / \mathrm{cm}^{3}$, comparable in magnitude to the value $2.37 \mathrm{~g} / \mathrm{cm}^{3}$ used by Garrand (1974) for rock of slightly lower (25.5 weight percent) $\mathrm{P}_{2} \mathrm{O}_{5}$ content than the 28.0 weight percent $\mathrm{P}_{22} \mathrm{O}_{5}$ for surface phosphate rock.

\section{PHOSPHORUS RESOURCE}

The resource of phosphorus in the Meade Peak Phosphatic Shale Member is in the map areas (fig. 1) designated "Outcrop of the Phosphoria Formation" and "Underlain by the Phosphoria Formation." The outcrop area includes deposits at or near the surface, and the area underlain by the Phosphoria comprises the deeply buried, or underground, resource. The area of deeply buried phosphorus resources is divided into subareas deeper and shallower than $600 \mathrm{~m}$ (fig. 6 ). The resource areas, which were measured from geologic maps, 


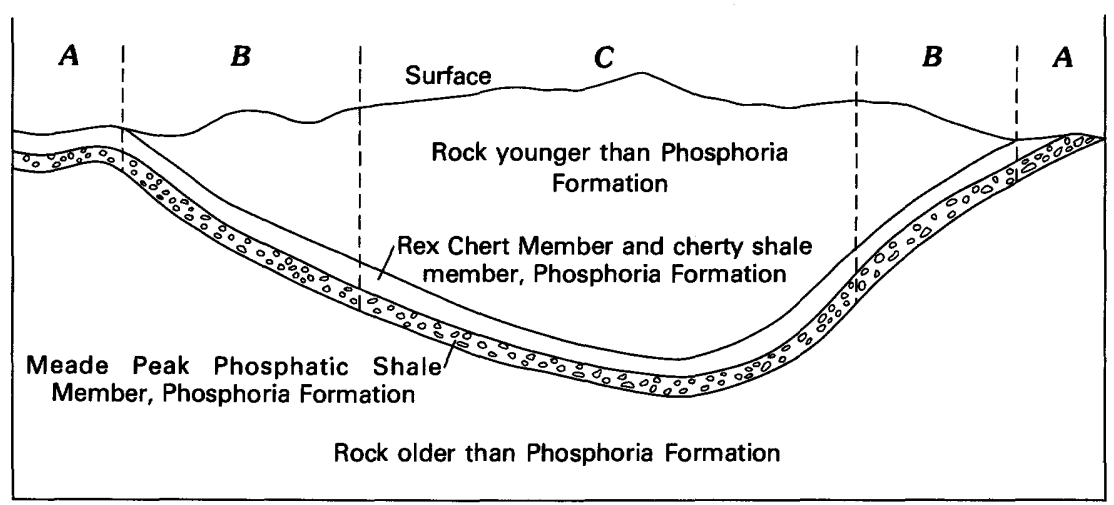

FIGURE 6.-Diagrammatic cross section showing resource categories:

A, Resource underlying outcrop of the Phosphoria Formation.

B, Deeply buried resource underlying rock younger than the Phosphoria Formation and shallower than $600 \mathrm{~m}$.

C, Deeply buried resource underlying rock younger than the Phosphoria Formation and deeper than $600 \mathrm{~m}$.

using cross sections and utilizing all available structural and stratigraphic information, are bedding-plane areas-that is, map areas corrected for the dip of the beds. These areas make up a total area about 22 percent greater than the map area.

Using rock parameters measured or derived above, we can calculate: (1) the phosphorus resource of the Soda Springs area in deeply buried phosphate rock (containing more than 20 weight percent $\mathrm{P}_{2} \mathrm{O}_{5}$ ) and in surface or near-surface phosphate rock (containing more than 20 weight percent $\mathrm{P}_{2} \mathrm{O}_{5}$ ) underlying outcrop of the Phosphoria Formation; and (2) the total phosphorus resource in phosphate rock (containing more than 20 weight percent $\mathrm{P}_{2} \mathrm{O}_{5}$ ) and in the entire Meade Peak (table 7).

We consider our calculation of the phosphorus resources to be reasonably accurate owing to the high quality and large quantity of data available for this assessment. Although direct information about the deeply buried rock is scanty, the derived parameters appear to us to be soundly based and unlikely to be greatly in error. Although the areas measured are partly speculative, they are based also on much geologic information, and we consider that they are not likely to be in error by more than 15 to 20 percent. We believe that the estimated resource reported above is probably a minimum for this area because all the rock currently being mined for fertilizer products is first calcined to remove organic matter, a process that raises the grade of the phosphate rock. Although we did not take this factor into account in our calculations, it increases the thickness of deeply buried rock that could be included in the phosphate rock class and consequently in- 
TABLE 7.-Resource of phosphorus in the Meade Peak Phosphatic Shale Member in Soda Springs area

\begin{tabular}{|c|c|c|c|c|c|c|c|c|c|}
\hline Rock class & $\begin{array}{l}\mathrm{P}_{2 .} \mathrm{O}_{5} \text { (average } \\
\text { weight percent) }\end{array}$ & $\begin{array}{l}\text { Thickness } \\
(\mathrm{m})\end{array}$ & $\begin{array}{c}\text { Area } \\
\left(\mathrm{km}^{2}\right)\end{array}$ & $\underset{\left(\mathrm{km}^{3}\right)}{\text { Volume }}$ & $\begin{array}{l}\text { Density } \\
\left(\mathrm{g} / \mathrm{cm}^{3}\right)\end{array}$ & $\begin{array}{c}\text { Rock } \\
\left(10^{*} \text { tons }\right. \\
\left.\text { s. }^{*}\right)\end{array}$ & $\underset{\left(10^{4} \text { tons }\right.}{\mathrm{P}_{9} \mathrm{O}_{5}}$ & $\underset{\left(10^{4} \text { tons*) }\right.}{\mathrm{P}}$ & $\begin{array}{l}\mathrm{P}_{8} \mathrm{O}_{5} / \text { hectare } \\
\left(10^{3} \text { tons } \mathrm{s}^{*}\right)\end{array}$ \\
\hline \multicolumn{10}{|l|}{ Phosphate rock $\left(>20\right.$ wt pct $\left.\mathrm{P}_{2} \mathrm{O}_{5}\right)$} \\
\hline Deeply buried, total & 27.7 & 10.6 & 780 & 8.3 & 2.64 & 22.0 & 6.1 & 2.7 & 78 \\
\hline$<600 \mathrm{~m}$ deep & 27.7 & 10.6 & 350 & 3.7 & 2.64 & 9.8 & 2.7 & 1.2 & 78 \\
\hline$>600 \mathrm{~m}$ deep & 27.7 & 10.6 & 430 & 4.6 & 2.64 & 12.1 & 3.4 & 1.5 & 78 \\
\hline \multicolumn{10}{|l|}{ Underlying outcrop of Phosphoria } \\
\hline Formation & 28.0 & 15.0 & 140 & 2.1 & 2.39 & 5.0 & 1.4 & .6 & 100 \\
\hline Total _. & ----- & ---- & 920 & $-\ldots$ & ------ & 27.0 & 7.5 & 3.3 & ------ \\
\hline $\begin{array}{l}\text { Entire Meade Peak Phosphatic } \\
\text { Shale Member }\end{array}$ & 10.8 & 54.0 & 920 & 49.7 & 2.51 & 1250 & 135 & 5.9 & 150 \\
\hline
\end{tabular}

*Metric tons. 
creases the total phosphorus resource in the area.

The total resource in the Soda Springs area in the class of rock that contains more than 20 weight percent $\mathrm{P}_{2} \mathrm{O}_{5}$ is estimated to be 3.3 billion tons of phosphorus, about 2.7 billion tons ( 82 percent) of which is deeply buried. About 44 percent of this resource is shallower than $600 \mathrm{~m}$, and all is shallower than about $2,000 \mathrm{~m}$. These deeply buried deposits are rich in phosphorus and capable of yielding 78,000 tons of $\mathrm{P}_{2} \mathrm{O}_{3}$ per hectare of bedding plane, a value that promises high efficiency in the ratio of ground handled or disturbed per unit of recovered product. Another measure of richness is that this deeply buried phosphate rock contains about 46 percent of the total phosphorus content of the entire Meade Peak Phosphatic Shale Member.

The reserve of phosphate rock in the Soda Springs area, estimated currently at about 1 billion tons, makes up about 20 percent of the resource underlying outcrop of the Phosphoria Formation. Much of this resource remaining after the reserve is mined may be exploited in the future if surface mining is not restricted by environmental considerations.

The deeply buried phosphorus resource in the Soda Springs area is very large yet constitutes probably only about 15 percent of similar resources that were calculated by Bauer and Dunning (1979) for all of southeastern Idaho below lat $43^{\circ} \mathrm{N}$. The very large quantity and richness of this resource makes it especially important to the United States for maintaining self-sufficiency in the supply of phosphorus far into the future. How close this resource is to being profitably mined and processed has not presently been established, but our study of the nature of the rock, as well as recent underground mining tests, provides information on the status of the problem.

Methods of processing the deeply buried phosphate rock may not differ greatly from those currently used for surface rock. The deeply buried rock differs principally in its higher content of organic matter and carbonate minerals. The organic matter could be removed by ordinary calcining, as is presently done. The increase in the proportion (by about double) of carbonate minerals would be unfavorable, especially in the amount of magnesium from dolomite, but may still be acceptable. If not, the dolomite could be removed, though at an increased processing cost. Other known methods of fertilizer manufacture may be even more efficient and less expensive in processing the deeply buried rock. Further studies need to be undertaken in this regard.

Until 1975, large-scale underground mining was not considered feasible. However, the plan of Earth Sciences, Inc., for underground mining in the Paris-Bloomington area of southeastern Idaho has created new interest in this possibility. Even though Earth Sciences, 
Inc., has successfully demonstrated machine mining of the partially weathered rock from their shallow mine, the capability of machine mining fresh deeply buried rock has yet to be established. The mining of all the underground phosphate rock may soon be possible, but further experimental work needs to be undertaken promptly to ensure that the technology is available when needed.

Whatever economic advantage that surface mining had over underground mining has in recent years been declining owing to the steadily increasing costs that surface mining must pay for protection and reclamation of the surface environment. By way of comparison, the surface environmental effects of underground mining are minimal. If environmental concern continues to increase, underground mining may be needed even sooner than current production trends would indicate.

\section{METHOD OF CALCULATING THE AVERAGE ROCK COMPOSITION OF A SECTION IN TERMS OF THREE COMPONENTS}

The calculation of rock composition in terms of three components requires the determination of only two of the components, the third being the remainder. Apatite, one component, is the product of the average weight percent $\mathrm{P}_{2} \mathrm{O}_{5}$ in a section and the factor 2.6. OM-carb, the second component, is derived from chemical analyses of phosphate rock, carbonate rock, and quartz-silicate rock, the three major rock types of the Meade Peak Phosphatic Shale Member (Gulbrandsen, 1966, 1975).

The proportion of carb is calculated from the total $\mathrm{CO}_{2}$ determined for each rock type minus the amount of $\mathrm{CO}_{2}$ in the apatite, which averages 1.7 weight percent $\mathrm{CO}_{2}$ :

$$
\mathrm{CO}_{2(\text { (arb) }}=\mathrm{CO}_{2(\text { total })}-\mathrm{CO}_{2(\text { apatite })} \text {. }
$$

Multiplying this result by the factor 2.15 yields an estimate of combined dolomite and calcite (carb) that slightly favors dolomite.

The combined OM-carb for each rock type is, then, the sum of the percentages of OM and carb, as shown below:

\begin{tabular}{|c|c|c|}
\hline OM & carb & OM-carb \\
\hline Phosphate rock & 2.52 & 4.83 \\
\hline Carbonate rock & 75.27 & 77.19 \\
\hline Quartz-silicate rock & 5.29 & 7.67 \\
\hline
\end{tabular}

The percentages of $\mathrm{OM}$-carb in the three rock types are multiplied next by the respective proportions of each rock type in each of the 17 surface sections. The sum of these three products yields, finally, the OM-carb content of a given section. 


\section{COMPOSITION, POROSITY, AND DENSITY OF AVERAGE SURFACE PHOSPHATE ROCK (CONTAINING MORE THAN 20 WEIGHT PERCENT $\left.\mathrm{P}_{2} \mathrm{O}_{5}\right)$}

To calculate the density of the surface phosphate rock, we need to know its composition and porosity. We know the apatite content (72.8 percent) from the data on the 17 surface sections, but not the proportions of OM-carb and Q-S. The OM and carb are obtained from the data on average phosphate rock of the Meade Peak Phosphatic Shale Member (Gulbrandsen, 1966), adjusted to the slightly lower apatite content of the surface phosphate rock. The $\mathrm{Q}-\mathrm{S}$ component, then, makes up the remainder of the rock. The composition of the surface phosphate rock determined in this way is:

$$
\begin{aligned}
\text { apatite } & =72.8 \text { percent } \\
\mathrm{OM} & =2.8 \text { percent } \\
\text { carb } & =3.0 \text { percent } \\
\mathrm{Q}-\mathrm{S} & =21.4 \text { percent }
\end{aligned}
$$

An estimate of the porosity of the surface rock is obtained by "weathering" the underground phosphate rock and thereby reducing the contents of $\mathrm{OM}$ and carb to the proportions present in the surface rock, as shown above, while holding the remaining rock volume constant. The volumes and weights of apatite and $\mathrm{Q}-\mathrm{S}$, therefore, remain the same as those shown in table 6 . The other known parameters are

\begin{tabular}{|c|c|c|c|c|}
\hline$\overline{\text { Componen }}$ & $\begin{array}{l}\text { Weight } \\
\text { percent }\end{array}$ & $\begin{array}{c}D \\
\left(\mathrm{~g} / \mathrm{cm}^{3}\right)\end{array}$ & $\begin{array}{c}V \\
\left(\mathrm{~cm}^{3}\right)\end{array}$ & $\begin{array}{l}W \\
(\mathrm{~g})\end{array}$ \\
\hline Apatite & -78.5 & 3.2 & 0.5940 & 1.9008 \\
\hline Carb - - & $-\quad 3.0$ & 2.8 & .0259 & .0726 \\
\hline $\mathrm{OM}_{\ldots}$ & $-\quad 2.8$ & 1.5 & .0452 & .0678 \\
\hline \multirow[t]{2}{*}{$\mathrm{Q}-\mathrm{S}$} & -15.7 & 2.6 & .1462 & .3801 \\
\hline & \multicolumn{2}{|c|}{ Subtotal } & .8113 & $\bar{m}$ \\
\hline \multirow[t]{2}{*}{ Void } & \multirow{2}{*}{\multicolumn{2}{|c|}{ Total }} & .1887 & \\
\hline & & & $\overline{1.0000}$ & $\overline{2.4213}$ \\
\hline
\end{tabular}
the final percentages of OM ( 2.8 percent) and carb ( 3.0 percent). The data on this "weathered" rock are summarized below in tabular form (see table 4 for explanation of terms):

We know that

$W_{\mathrm{ap}}+W_{\mathrm{c}-\mathrm{S}}=100$ percent -2.8 percent $(\mathrm{carb})-3.0$ percent $(\mathrm{OM})=$ 94.2 percent, yielding a total weight for $1 \mathrm{~cm}^{3}$ (that is, a density) of $W_{\text {total }}=\frac{W_{\mathrm{ap}}+W_{\mathrm{Q}-\mathrm{S}}}{0.942}=\frac{2.2809 \mathrm{~g}}{0.942}=2.4213 \mathrm{~g}$;

therefore,

$W_{\text {oM }}=\frac{\text { percent OM }}{100} \times W_{\text {total }}=\frac{2.8}{100} \times 2.4213=0.0678 \mathrm{~g}$, 


$$
\begin{aligned}
& W_{\text {carb }}=\frac{\text { percent carb }}{100} \times W_{\text {total }}=\frac{3.0}{100}=\times 2.4213=0.0726 \mathrm{~g}, \\
& V_{\mathrm{OM}}=\frac{W_{\mathrm{OM}}}{D_{\mathrm{OM}}}=\frac{0.0678 \mathrm{~g}}{1.5}=0.0452 \mathrm{~cm}^{3}, \\
& V_{\text {carb }}=\frac{W_{\text {carb }}}{D_{\text {carb }}}=\frac{0.0726 \mathrm{~g}}{2.8}=0.0259 \mathrm{~cm}^{3}, \\
& V_{\text {ap }}+\text { oM }+ \text { carb }+\mathrm{Q}-\mathrm{s}=0.8113 \mathrm{~cm}^{3}, \\
& V_{\text {void }}=V_{\text {total }}-V_{\text {ap }}+\text { oM }+ \text { carb }+\mathrm{Q}-\mathrm{s}=1-0.8113=0.1887 \mathrm{~cm}^{3}, \\
& \text { and } P=V_{\text {void }} \times 100=0.1887 \times 100=18.87 \text { percent. }
\end{aligned}
$$

To complete the data calculations, the percentages of apatite and $\mathrm{Q}-\mathrm{S}$ are given by their respective weights divided by the total weight of the rock.

Using the above estimate of porosity and the composition given previously, we can now calculate the density of the surface phosphate rock. We note that the "weathered" underground phosphate rock from which the value for porosity was derived has different amounts of

\begin{tabular}{|c|c|c|c|c|c|}
\hline Component & $\begin{array}{l}\text { Weight } \\
\text { percent }\end{array}$ & $\underset{\left(\mathrm{g} / \mathrm{cm}^{2}\right)}{D}$ & $r V$ & $\underset{\left(\mathrm{cm}^{3}\right)}{V}$ & $\begin{array}{l}W \\
(\mathrm{~g})\end{array}$ \\
\hline Apatite - & -72.8 & 3.2 & 0.2275 & 0.54413 & 1.7412 \\
\hline Carb _- & 3.0 & 2.8 & .0107 & .02560 & .0716 \\
\hline $\mathrm{OM}_{\ldots}$ & 2.8 & 1.5 & .0187 & .04473 & .0671 \\
\hline Q-S & 21.4 & 2.6 & .0823 & .19684 & .5118 \\
\hline \multirow{3}{*}{ Void } & & Subtotal & .3392 & .8113 & $-\ldots$ \\
\hline & & & .0789 & .1887 & $\ldots$ \\
\hline & & Total &.$\overline{4181}$ & $\overline{1.0000}$ & $\overline{2.391}$ \\
\hline
\end{tabular}
apatite and $\mathrm{Q}-\mathrm{S}$ from the surface phosphate rock because the surface rock includes the rock that in its unweathered state contains less than 20 weight percent $\mathrm{P}_{2} \mathrm{O}_{5}$.

The data and a description of the calculation are presented below (see table 4 for explanation of terms):

Known variables: weight percent, $D$, and porosity $(P)=18.87$ percent $=100 V_{\text {void }}$.

Sequence of calculations:

(1) to obtain density: $r V_{\text {components, }} r V_{\text {subtotal }}, V_{\text {subtotal }}=V_{\text {total }}-V_{\text {void }}$ $=1-0.1887=0.8113 \mathrm{~cm}^{3}, r V_{\text {total }}=r V_{\text {subtotal }} / V_{\text {subtotal }}=\frac{0.3392}{0.8113}=$ 0.4181 , and

$D_{b}=1 / r V_{\text {total }}=2.39$;

(2) to complete data of table: $r V_{\text {void }}, V$, and $W$. 


\section{REFERENCES CITED}

Altschuler, Z. S., 1973, The weathering of phosphate deposits-geochemical and environmental aspects, in Griffith, E. J., Beeton, Alfred, Spencer, J. M., and Mitchell, D. T., eds., Environmental phosphorus handbook: New York, John Wiley \& Sons, p. 33-96.

Armstrong, F. C., 1969, Geologic map of the Soda Springs quadrangle, southeastern Idaho: U.S. Geological Survey Miscellaneous Geologic Investigations Map I-557, scale $1: 48,000,2$ sheets.

Armstrong, F. C., and Cressman, E. R., 1963, The Bannock thrust zone, southeastern Idaho: U.S. Geological Survey Professional Paper 374-J, p. J1-J22.

Athy, L. F., 1930, Density, porosity, and compaction of sedimentary rocks: American Association of Petroleum Geologists Bulletin, v. 14, no. 1, p. 1-24.

Bauer, C. W., and Dunning, C. P., 1979, Uraniferous phosphate resources of the Western Phosphate Field, chap. 3 in Uraniferous phosphate resources, United States and Free World, v. 1 of De Voto, R. H., and Stevens, D. N., Uraniferous phosphate resources and technology and economics of uranium recovery from phosphate resources, United States and Free World: Golden, Colo., Earth Sciences, Inc., p. $123-247$.

Carswell, L. D., and Gulbrandsen, R. A., 1954, Variation in composition of phosphate rock with depth in the Conda mine [Idaho], in Geologic investigations of radioactive deposits: U.S. Geological Survey Trace Elements Investigations Report 540, p. 192.

Cathcart, J. B., and Gulbrandsen, R. A., 1973, Phosphate deposits, in Brobst, D. A., and Pratt, W. P., eds., United States mineral resources: U.S. Geological Survey Professional Paper 820, p. 515-525.

Cressman, E. R., 1964, Geology of the Georgetown Canyon-Snowdrift Mountain area, southeastern Idaho: U.S. Geological Survey Bulletin 1153, 105 p.

Crèssman, E. R., and Gulbrandsen, R. A., 1955, Geology of the Dry Valley quadrangle, Idaho: U.S. Geological Survey Bulletin 1015-I, p. 257-270.

Davidson, D. F., Smart, R. A., Peirce, H. W., and Weiser, J. D., 1953, Stratigraphic sections of the Phosphoria Formation in Idaho, 1949, part 2: U.S. Geological Survey Circular 305,28 p.

De Voto, R. H., and Stevens, D. N., eds., 1979, Uraniferous phosphate resources and technology and economics of uranium recovery from phosphate resources, United States and Free World: Golden, Colo., Earth Sciences, Inc., 2 v.

Emigh, G. D., 1972, World phosphate reserves-are there really enough?: Engineering and Mining Journal, v. 173, no. 4, p. 90-95.

1973, Economic phosphate deposits, in Griffith, E. J., Beeton, Alfred, Spencer, J. M., and Mitchell, D. T., eds., Environmental phosphorus handbook: New York, John Wiley \& Sons, p. 97-116.

1975, Phosphate rock, in Industrial minerals and rocks (4th ed.): New York, American Institute of Mining, Metallurgical, and Petroleum Engineers, p. 935962.

Garrand, L. J., 1974, Phosphate reserves of southeastern Idaho: Pocatello, Idaho, U.S. Forest Service unpublished report, n. p.

Gulbrandsen, R. A., 1966, Chemical composition of phosphorites of the Phosphoria Formation: Geochimica et Cosmochimica Acta, v. 30, no. 8, p. 769-778.

__ 1975, Analytical data on the Phosphoria Formation, western United States: U.S. Geological Survey Open-File Report 75-554, 45 p.

Gulbrandsen, R. A., McLaughlin, K. P., Honkala, F. S., and Clabaugh, S. E., 1956, Geology of the Johnson Creek quadrangle, Caribou County, Idaho: U.S. Geological Survey Bulletin 1042-A, 23 p. 
Hale, L. A., ed., 1967a, Anatomy of the western phosphate field-a guide to the geologic occurrence, exploration methods, mining engineering, recovery technology: Salt Lake City, Utah, Intermountain Association of Geologists, 287 p.

1967b, Phosphate exploration using gamma-radiation logs, Dry Valley, Idaho, in Hale, L. A., ed., Anatomy of the western phosphate field-a guide to the geologic occurrence, exploration methods mining engineering, recovery technology: Salt Lake City, Utah, Intermountain Association of Geologists, p. 147-160.

Hedberg, H. D., 1936, Gravitational compaction of clays and shales: American Journal of Science, ser. 5, v. 31, no. 184, p. 241-287.

Mabey, D. R., and Oriel, S. S., 1970, Gravity and magnetic anomalies in the Soda Springs region, southeastern Idaho: U.S. Geological Survey Professional Paper 646-E, p. E1-E15.

McKelvey, V. E., 1967, Phosphate deposits: U.S. Geological Survey Bulletin 1252-D, p. D1-D21.

McKelvey, V. E., Armstrong, F. C., Gulbrandsen, R. A., and Campbell, R. M., 1953a, Stratigraphic sections of the Phosphoria Formation in Idaho, 1947-48, part 2: U.S. Geological Survey Circular 301, 58 p.

McKelvey, V. E., Cathcart, J. B., Altschuler, Z. S., Swanson, R. W., and Buck, K. L., 1953b, Domestic phosphate deposits, in Soil and fertilizer phosphorus in crop nutrition: Agronomy monograph 4: New York, Academic Press, p. 347-376.

McKelvey, V. E., Davidson, D. F., O'Malley, F. W., and Smith, L. E., 1953c, Stratigraphic sections of the Phosphoria Formation in Idaho, 1947-48, part 1: U.S. Geological Survey Circular 208, 49 p.

McKelvey, V. E., and others, 1959, The Phosphoria, Park City, and Shedhorn formations in the western phosphate field: U.S. Geological Survey Professional Paper 313-A, 47 p.

Mansfield, G. R., 1927, Geography, geology, and mineral resources of part of southeastern Idaho: U.S. Geological Survey Professional Paper 152, 453 p.

Montgomery, K. M., and Cheney, T. M., 1967, Geology of the Stewart Flat quadrangle, Caribou County, Idaho: U.S. Geological Survey Bulletin 1217, 63 p.

O'Malley, F. W., Davidson, D. F., Hoppin, R. A., and Sheldon, R. P., 1953, Stratigraphic sections of the Phosphoria Formation in Idaho, 1947-48, part 3: U.S. Geological Survey Circular 262, $43 \mathrm{p}$.

Rioux, R. L., Hite, R. J., Dyni, J. R., and Gere, W. C., 1975, Geologic map of the Upper Valley quadrangle, Caribou County, Idaho, U.S. Geological Survey Geologic Quadrangle Map GQ-1194, scale 1:24,000.

Rubey, W. W., and Hubbert, M. K., 1959, Role of fluid pressure in mechanics of overthrust faulting. II. Overthrust belt in geosynclinal area of western Wyoming in light of fluid-pressure hypothesis: Geological Society of America Bulletin, v. 70, no. 2, p. $167-205$

Sheldon, R. P., 1969, World phosphate resources: Mining Congress Journal, v. 55, no. 2, p. 115-118.

Sheldon, R. P., Warner, M. A., Thompson, M. E., and Peirce, H. W., 1953, Stratigraphic sections of the Phosphoria Formation in Idaho, 1949, part 1: U.S. Geological Survey Circular 304, $30 \mathrm{p}$.

Smart, R. A., Waring, R. G., Cheney, T. M., and Sheldon, R. P., 1954, Stratigraphic sections of the Phosphoria Formation in Idaho, 1950-51: U.S. Geological Survey Circular 327, $22 \mathrm{p}$.

Stowasser, W. F., 1975, Phosphate rock, in Mineral facts and problems: U.S. Bureau of Mines Bulletin 667, $16 \mathrm{p}$.

Wells, F. J., 1975, The long-run availability of phosphorus: Baltimore, Md., John Hopkins University Press, 121 p. 



\section{GPO $689-143 / 17$}



